\title{
L'enseignement du docteur William Cullen, d'Edimbourg (1712-1790) transcrit par son élève le docteur Louis Odier de Genève (1748-1817)
}

Par Marc Cramer et Georges de Morsier

Le Musée d'Histoire des Sciences de Genève possède un manuscrit très important, entièrement inédit. Il s'agit de la reproduction des Cours professés par Cullen à Edimbourg en 1770, en 23 volumes reliés. 13 sont intitulés «Cullen ${ }^{\mathrm{s}}$ Practice». Ce sont des leçons de médecine théorique dans lesquelles il expose sa doctrine. On sait que, partant du principe que le système nerveux est à l'origine et à la base de tous les phénomènes de la vie, il en déduit que tous les corps qui agissent sur l'organisme ne le font qu'en modifiant ce système. Toutes les maladies dépendent donc d'une affection du système nerveux, et toute la pathologie a pour base le «spasme» ou l'«atonie» de ce système. Nous ne parlerons pas ici du système de Cullen ni de sa classification des maladies car son élève Louis Odier, qui les a adoptés presque entièrement, les a exposés dans son ouvrage Manuel de Médecine pratique $\left(3^{\mathrm{e}}\right.$ édition, 1821) dont l'un de nous a parlé longuement dans une récente monographie sur La vie et l'œuvre de Louis Odier, Docteur et Professeur en médecine, qui paraîtra prochainement. Par contre, nous allons parler des 10 volumes intitulés par Cullen «Clinical Cases», dans lesquels sont rapportées une quantité d'histoires de malades, avec la description des symptômes et les prescriptions thérapeutiques. Après chaque cas se trouvent des «Remarks» qui sont un résumé du cas et dans lesquelles l'auteur discute l'intérêt qu'il présente pour la doctrine et sa comparaison avec d'autres cas semblables.

Dans le tome 1 se trouvent 26 cas cliniques : 12 sont rapportés par Cullen, 10 par le $\mathrm{D}^{\mathrm{r}}$ Home (un disciple de Cullen, ami d'Odier) et 5 par Odier. Dans le tome 2 il n'y a qu'un seul cas de lui. Nous examinerons tout d'abord les cas observés par Odier.

Dans son livre L'Officine ou Répertoire général de Médecine pratique ( $4{ }^{\mathrm{e}}{ }^{\text {édition, }}$ 1855) Dorvault donne les «signes abréviatriques des mesures anglaises» (p. 77) employés par Cullen, Odier et Home :

$\mathrm{M}=$ Minimum : $60^{\mathrm{e}} \mathrm{du}$ fluidrachme.

$\mathrm{F}_{z}=$ Fluidrachma : $8^{\mathrm{e}}$ de la fluidonce.

$\mathrm{F}_{z}=$ Fluidoncia : $20^{\mathrm{e}}$ de la pinte. $z=$ once.

$\mathrm{O}=$ Octarius : Pinte. $8^{\mathrm{e}}$ du gallon.

$\mathrm{C}=$ Congius: Gallon.

$\beta=\mathrm{j} \beta=1 / 2$ 
Dans les cas d'Odier (Peter Chalmarl et Sanders Douglas) des ordonnances contiennent un signe qui est probablement la lettre grecque xi dont la signification nous est donnée par Dorvault.

$\mathrm{D}^{\mathrm{r}}$ Odier

Synochus Peter Chalmarl, ag.6.

Sunday 4 Nov. 1770.

On Monday last 29 Oct., was seized with Coldness, and Shivering, Head-ake, Lassitude and pains, followed with heat, thirst, wich complaints of universal pains, chiefly Head-ake. Skin hot. Pulse 88. Has no stool since Monday. Has a constant Nausea and inclination to vomit. Great thirst. Sleeps little. Cold Feat. Has taken nothing but water gruel, and has now more coverings than usual. Let his extraordinary covering be taken off. Let him have an hot brick or Iron at the foot of his bed. Let him drink Barley-water with Vinaigar. H. 6. Vesp. C. Pulver. 9 p. gr vj. pro Em and Si h g â alv. non dejec. Inj. En Salin.

$$
\text { 5-6 [Nov.] }
$$

As he lived at 2 miles distance, a woman came to tell me he was no better, but could bring no distinct account except that the vomit operated well, but he was no better.

$$
7 \text { [Nov.] }
$$

She came back again to tell me he had had a passage of his belly wether by the Clyster or not, she could not tell. But she said he was the same and his Head-ake very great. apl. Empl. Episp. tergo.

$$
10 \text { [Nov.] }
$$

Was relieved as for his Head-ake by the Blister. Had a bleeding at his nose in the night between Thursday and Friday. Is rather better now. Urine still red and transparent. Skin hot. Rp Tart. Em. gr. j $\beta$. Aq. Font ounces iij M. Cap. Cochl. j. omni semi-hor. nisi prius vomit. Supervenit.

\section{7 [Nov.]}

Was a little sick with the Tartar, sweated much after it, and has been much better since. Cured.

\section{Remarks}

There was at that time in Edimb. a contagious fever of wich this was one case. It offers nothing particular except a great determination to the head, wich was pretty common in young people. Nature relieved it in the night of the $11^{\text {th }}$ to the $12^{\text {th }}$ day of the disease, and the Tartar emetic finished the cure. 
$\mathrm{D}^{\mathrm{r}}$ Odier.

Ephemera.

Peguy Craick, ag. 20-25.

18 Sept. 17704 o'clock

Has not been well for days past; but had wandering pains, with schiverings at times, attended with constant weakness, was seized yesterday, or the day before, with cold and shivering, followed by Heat and Thirst, great Head-ake, pains all over her body, chiefly at the breast. No Dyspnea, no Cough, no Nausea, no Sickness, Belly and Menses regular. Has been distressed with love-affair for sometime past, and particulary of late. Is a servant of $\mathrm{M}^{\mathrm{rs}}$ Craick. Is now weak, somewhat hot, but inequally. Skin dry. Thirst. Great head-ake. Pains all over her body, chiefly at her breast. She hates vomiting and is always, as she says, the worse for it. Pulse weak, small, unequal, at 130. Rp Tart. Emet. gr. j $\beta$. Solve in aq. Fluidoncia iij. Cap. Cochl. j h â 6 â and rep. omni $2^{\circ} \mathrm{min}$, nisi prius evomat.

\section{8 o'clock}

Took the Tartar, wich made her sick, but she did not vomit. Is rather better. Sweats a little, great Head-ake still. Pain at her breast rather worse. Pulse 96, equal and fuller. Let her drink acidulated water gruel.

\section{Sept., 10 o'clock forenoon.}

Sweated much in the night. great Head-ake still. Pain at her breast much the same. Less hot and thirsty. Slept better than the nights before. Upon the whole, feels herself better. Pulse 100 and soft. Does not ... [un mot illisible] a Blister on he head. Aplic. Empl. Epispasticum inter scapulas. Let her drink acidulated Barley-water pro. pot. comm.

\section{9 [Sept.] 4 l'cl. aftern.}

Pulse 92 and soft. Is now much better. Head-ake almost gone. Back very sore with the Blister. Belly regular. Feet cold. Let her have more bed-cloaths on the foot of her bed only. Rp Tart. Em. gr. ij. Solve in aqu. Fluidoncia iij. Caps Cochl. j. h. 6 â n. av.

$$
8 \text { o'clock }
$$

Was sick with the Tartar, but she did not vomit. Pulse 96, full and equal. Head-ake, and particulary pain of breast a little returned. Sweats a little. Blister rose well.

20 Sept.

Is quite well, but weak; pulse regular. Let her rise and eat a little. Cured. 


\section{Remarks}

It is doubtfull wether this fever would not have proved a Typhus if recovery had not been hard to Tartar emetic, the dose of wich however seemed to renew her head-ake and the pain of her breast. But it is to be remarked that there are some Ephemera wich begin one of this kind in $D^{r}$ Dunant at Paris of wich the cold fit lasted two hours and was attended with much longer and almost syncope. The hot fit lasted three or four hours during wich he slept upon a chair and then he sudated a little and the fever was then terminated the same day, an eruption appearing at the sametime on his lips. It was probably occasioned by the sight of a bad ulcers... [un mot illisible] in hospital.
$\mathrm{D}^{\mathrm{r}}$ Odier.
George Creghy, ag. 40-50
Sprain.
Thursday 15 Nov. 1770

In carrying a spinet on his back down Leith-wynd, fell down and sprained his foot. However, he continued to walk for the rest of the day, and even this morning, but with much difficulty. Now he is in this bed; the foot is much swelled and inflamed. He does not feel much pain, but great torpor in it and he cannot move it. Aplic. catapl. pane and Lacte calide factum parte del Stat. When the swelling and redness abates, Fiat fomentatio indentidem cum aqua calidâ et aceto et dim fricatur and moveatur pes quantum potevit sine multo dolore.

16 Nov. Is better, but cannot yet walk well. Continue. Lavetur indentidem pes cum Aq. Vitae.

17 Nov. Is much better, except a very little torpor in the foot, walks much better and almost quite well. Utatur pediluvio frigido saepe. Cont. aq. vitae. Let him walk much.

18 [Nov.] Is quite well. Foot with any pain. Walks as well as ever. Cured.

\section{Remarks}

This disease in delicate peoples lasts often much longer and I imagine it is because when the inflammation is gone, they do not take exercise enough. It arises from a great distension of the ligaments and therefore after the swelling and Inflammation is diminished, it is proper to strengthen the part by spirits, frictions, exercises and cold Baths.

$\mathrm{D}^{\mathrm{r}}$ Odier.

Synochus William Dick, ag. 25-30.

Was seized on Sunday evening 21 Oct. 1770 with Coldness and shivering succeded by Heat, Thirst, and pains all over his body. Nausea and Inclination 
to vomit. These complaints continue, and he has moreover a sore throat wich makes his deglutition difficult. Pulse 90. Belly bound since Sunday.

Thursday 25 Oct. Rp Ypec. gr. x pro Em. Caps. h. 6 esp. If at 9 he has no stool, Inj. Enem. Let him wash his throat with a gargarism of Honey and Vinaigar.

26 [Oct.]. Slept non for dryness in his throat, having neglected to wash it with the gargarism ordered. Had a stool before the vomit was taken, so did not take the clyster. Vomit operated well. Is now better and in a Sweat. Let him wash his throat often with the gargarism prescribed. Let him drink Barley-water with Vinaigar.

27 [Oct.]. Is much better and all symptoms of convalescence.

28 [Oct.]. No complaints. Cured.

\section{Remarks}

Was this an idiopathic sore throat and were the other symptoms to be considered as depending on it, or where they symptoms of a slight fever cured by the vomit and the sweat of the $26^{\text {th }}$, of wich fever the angina was to be considered as a topical determination? The latter appeared to me then and still does now more probable.

$\mathrm{D}^{\mathrm{r}}$ Odier.

Sanders Douglas, age 30-40

Sunday 21 April 1771. 12 o'clock.

Was on Thursday Last Seized with an acute pain in the left side, preceded with Cold and shivering, and attended with heat, want of sleep, difficult respiration and extremely troublesome Cough. He was bled on Fryday, but little relieved by it. His symptoms continue. Skin hot and dry. Pulse frequent and strong. Tongue moist and very clean. Belly regular, tho' loose in the beginning of this complaint. Cough very troublesome, with difficult expectoration of a gross viscid matter. Pain acute and much increased by the cough, wich he says is at the very place of the pain. Great Head-ake. Restlessness. No nausea, nor vomiting. Has taken no food, except water-gruel. It appears that his blood, tho' drawn in a broad flat plate, was covered with an inflammatory Crust. M. s. ounces X. statim.

5 o'clock. Was bled, as ordered. Blood covered with much Crust, tho' in the same plate as before. Has been a little relieved by it, for the pain and the Headake, but is still much troubled with the cough. Pulse softer and less frequent. Let him take water-gruel acidulated with vinaigar at night.

22 [April]. Pulse softer. Has sweated much in the night, after having taken the vinaigar and water-gruel as before. Slept none for the cough wich is very trouble- 
some. Pain lies on both sides, wich he as done since the beginning. Head-ake better. Would be pretty well if it was not the cough. Rp Mucilag. G. Arab. ounces iij. Syr. Balsam j. ounce Limon, 1/2 ounce M. Cap. Cochl. j. urgente tussi.

5 o'clock. Cough less troublesome with the Mixturer. Expectoration very copious and much easier. Pain and pulse as before. Cont. M.

24. April 1771. Pilse good. Still sweats at night. Easier since last visit, but sleeps none. Utatur pediluvio tepido, h. s.

25 [April]. Is much better. Took the pediluvium as ordered, sweated a little, and slept very well 10 o'clock at night till 6 in the morning. Sweated much in the night. Pain and Head-ake almost gone. Cough still continues. Cont. M. Mucil. Rep. Pedil. h. 5.

27 [April]. Without complaints, but of great weakness, and a little cough. Cured.

\section{Remarks}

This is a case of Pleuresy cured chiefly by Bleeding. The mucilaginous mixture had a very good effect in promouving the expectoration and the pediluvium in procuring sleep. The vinaigar seemed likwise to produce a sweat wich was usefull.

$\mathrm{D}^{\mathrm{r}}$ Odier.

\section{Anonyma, ag. 53 .}

Communicated to the Phy. Med. Society Febr. 1771.

Has for these 6 months complained of a violent fixed and constant pain of the left side of her head, directly above the left eye. About one month ago, she observed a distillation of matter into her nose, wich still continues and wich she supposes to proceed from her eye, the external teguments of wich are much affected with swelling and redness. She often complains of tooth-ake and pain of her upper jaw.

Frid. 25 Jan. 1771. Head-ake are much aggravated, with a sense of pulsation in the part, accompanied with pain of her back. Nausea, Thirst, alternate coldness of her feet with great redness and sweating about her breast and head with great redness and swelling of the left side of her face. Great debility. Prostration of appetite. Belly regular. Pulse soft and about 100 .

Frid. 29. Symptoms as above. Apl. Hirud. $n^{0}$ viij. temp. Sin. Rp. Sol. Tart. Em gr. 1/4. cap. o. semit. ad $3^{\text {am }}$ vic.

30. Two Leeches only fixed wich bled pretty freely and she was relieved by them. The 3 doses of the solution made her sick and vomit and gave her one stool. Head-ake relieved. Swelling abated. Rep. Tart. Em. apl. Hiv. Vj. temp. Sin. 
31. Only 3 Leeches fixed and pain rather easier. Tartar taken last night neither made her sick, nor vomited her but purged her. Towards 2 post merid. this day, a delirium came on, with coldness of her extremities. Pulse 100 and soft. Let her hair to be shaved, and apl. Empl. Episp. Cr M.

Frid. 1 Feb. 1771. as she turned worse last night, a Physician was called who countermanded the shaving of her head and ordered Sinapisms to her feet, and Tartar Emetic in $1 / 4$ grain, doses every 4 hours, and a blister between her Shoulders. Pulse soft. Delirium continues. Tartar Emetic produced no effect. Blister did not rise. Her head was again ordered to be schaved and was again countermanded. Cont. Tart. Emet.

Sat. 2 Feb. 1771. Delirium continues. Cont. Tart. Em.

3 [Feb.]. Pulse soft, full and about 100. Delirium continues with swelling of face, lower jaw fallen, difficulty of swallowing, spoke nothing distinctly the whole day. Eyelids shut. Lying constantly on her back with very little motion. Aplic. Hirud temp. Let her head be schaved.

4 [Feb.]. Leeches were by mistake applied to the other Temp without relief. The shaving of the head was contradicted by 2 young Gentlemen $\left(\mathrm{M}^{\mathrm{r}}\right.$ Edward and Withers) of the faculty, who thought it requisite without consulting the Physician or the Gentleman before employed to bleed her to the quantity of 3 breakfast cup full at 7 post meridiem wich they thought greatly relived her, but one of the aforsaid Gentlemen returning about 11 at night, said, upon being asked if it was proper to shave her head, that it was then too late, as she was dying, wich happened this morning at 6 a. Mer.

Wenesday Feb. 6. Dissection. By desire of her friends, her head was opened. The teguments wich before appeared and swelled above her left eye were now black. On raising the Cranium a block spot about the size of a shilling appeared on the forepart of the longitudinal sinus. The inner table of the os frontis was extremely thin, and the cellular part of the sinuses was almost entirely destroyed, and both full of purulent matter, and in the right a large clot of blood was found. On removing Dura mater, wich was thickened in the fore part, the whole anterior surface of the Brain, as far back as the fontanelle, was covered with thick pus; when this was removed, several pits, some of which would admit more than the point of the thumb, appeared particulary in the right side where the Pia Mater was destroyed. On cutting through the ... [un mot illisible] part the Medula was in a natural state, nore was there any effusion into any of the Ventricles. The Plexus choroideus was very large, having a number of small vesicles filled with water, and its blood vessels full and turgid. When the brain was taken out of the Scull, the Sinuses appeared turgid with blood and in the right orbicular plots of 
the frontal bone, there was a large black carious Spot, wich immediately fall in on the slightest pressure. On introducing a probe into the frontal sinuses, one passage was found seemingly towards the back part of the palate bone, and introduced in another direction, it passed into the antrum maxillare of the right side.

\section{Remarks}

Whatever might have been given to this woman, it is probable She should have died, since She laboured under a considerable suppuration of the brain. The matter wich came aniway by the nose and mouth before her death has probably been formed in one of the frontal sinuses. For, from the dissection it does not appear it could have found its way from the brain through the Cranium. The seat of the inflammation was then, at the same time, external and internal. I have seen a student in Edinburgh who died with all the symptoms of a Typhus.

Nous reproduirons encore deux cas observés par Cullen, un cas d'épilepsie et un cas d'hystérie.

$\mathrm{D}^{\mathrm{r}}$ Cullen.

Anne Stalker, ag. 19 Adm.5 Dec. 1770

Hysteria Epileptica

(Was a patient of $\mathrm{D}^{\mathrm{r}}$ Home in the Clinical ward last summer.) of a corpulent habit of body is commonly seized during her sleep at night with convulsions which last for some time during which she is totally insensible and foams at the mouth. These for the most part go off with schrieking and she falls asleep again immediately. This occurs sometimes $3^{\text {ce }}$ in the night. She has a constant propensity to sleep, and often as she indulges this in the day-time do the fits recur, those they do not every night and never at any time but in her sleep, except when moved by anger or surprise and then they are preceded with the globus. The fits are more frequent at the period of Catamenia wich are regular in point of time but increased in quantity. Appetite good. Belly and menses regular. Has been subject for several years to involuntary screaming, crying and laughing fits but the convulsions only first appeared about 6 months ago.

Friday 7 Dec. Symptoms as above. Rp Camph. gr. V. Sacch. alb. gr. X. Tevits simul. Cons. Rod. q. s. F. B. h. s. Sum.

8 [Dec.]. Has had no fits, but several fits of screaming in the night. Rps. Bol. Camph.

9 [Dec.]. Pulse 70, not full. Has had no fit but some screaming as the night before. Rp. Bol. Camph. gr vij. 
10 [Dec.]. Has had no fits and less screaming than before. Rp. Bol.

11 [Dec.]. Pulse 70. No fits, less screaming. Rp. Bol. ex Cyph. gr. X.

12 [Dec.]. Pulse 82. Had 2 epileptic fits about midnight. She had taken her Bolus about 9 in the evening. Rp. Bol. ex Cyph. M. S x.

Thursday 13 [Dec.] 1770. Pulse 82. Blood drawn yesterday shows no crust (Turbid Serum). Had no fit last night, but a good deal of screaming. Rp. Bol. ex Camph. Cr M. Cap. Dec. Tam. viij.

14. [Dec.]. Has had no fits. Physic has operated 3 or 4 times. Rp. Bol.

15 [Dec.]. No fits and little screaming. Without other complaints. Rp. Bol. ex Camph. gr XV.

16 [Dec.]. No fits, and less screaming than usual. Rp. Bol. ex Camph. Cr M. Reps. Dec. Tam. n. av.

17 [Dec.]. Pulse 80. Has had several fits this morning. Physic. taken this morning has operated several times. If the fits continue to occur this fornoon, Let her take the Camph. Bol. as order at night, but if the fits cease, Let the Boles be delayed till night and let it be ex Cph. gr XX.

18 [Dec.]. Had fits again last night. Her frequent screamings in the night are very troublesome to the other patients of the ward and she desires to be dimissed. Dimissed.

\section{Remarks}

This is a complication of Hysteria with Epilepsia wich proceeded from passions, jealousy and love. The girl was very plethoric. Her dreams were proably the chief occasional cause of her fits, as they returned mostly during the night. Neither Bleeding, nor purging, nor a very great dose of camphar had effects upon her.

Ce cas présente un certain intérêt. La patiente souffrait depuis plusieurs années de crises de rire et de pleurs involontaires et n'avait des crises que pendant son sommeil. Cullen pense que ses rêves étaient probablement la cause principale des crises et que sa maladie provenait de «passions, jalousie et amour». C'est un essai d'interprétation médicale des rêves près d'un siècle avant Alfred Maury (1861) et deux cent trente ans avant la naissance de la psychanalyse.

$\mathrm{D}^{\mathrm{r}}$ Cullen

Isab. McPherson, ag. 18.

Hysteria

Adm. Tuesday 11 Dec. 1770.

Was last Monday seized with great oppression at the praecordia, hickup and headake preceeded with a pain in her left side wich continued for about half an hour, and from thence was communicated to her Stomach, and produced sickness. 
It remained there for a little and then schifted to her throat where she had a sensation of globus and suffocation with difficulty at breathing and deglutition. After this she became insensible and continued so for about 10 minutes since that time she has had several fits of the same kind, with an almost constant hickup during their continuation. For some time past, she has been troubled with four Belchings, sinckness and vomiting at times, growzings, flushings [ces mots, bien lisibles dans le texte de Cullen, ne se trouvent pas dans les dictionnaires anglais actuels], transitory pains in head and back, propensity to sleep and great vertigo. Belly in general regular. Urine pale and in great quantity. She has trembling of her limbs often, and is subject to high and low spirits. Has been very irregular with respect to her menses for sometime. She formerlhy had them once in 3 weeks, but of late has had sometimes 3 months intervals. For two months at least before the last attack, she had been without any appearance of them.

\section{Remarks}

This is a case of Hysteria wich was cured by the Extr. Hyociami to the dose of 15 grains at night. It is to be remarked that in smaller doses it had no effect as a Laxative. But that, when it was increased to $15 \mathrm{gr}$. p. d., it operated as an Antispasmodic without having more effect on the belly.

Nous allons maintenant donner une statistique des 164 cas suivant le diagnostic des maladies posé par les médecins, par ordre de fréquence :

Catharus 18, Rheumatismus 11, Synochus 10, Erisipela 9, Typhus 8, Phtisis 7, Ascites 5, Hypochondrie 5, Catharus vesicae 5, Hemorrhois 4, Hematemesis 3, Peripneumonie 3, Hysteria epileptica 3, Anasarca 3, Leucorrhée 3, Hydrothorax 2, Tertiana 2, Nephritis 2, Rubeola 2, Variola 2, Lepra 2, Scrophula 2, Tetanus 2, Catharus dysenter. 1, Sprain 1, Angina 1, Hemoptoe 1, Melancholia 1, Pleuritis 1, Hydropis 1, Tumores 1, Abcessus cerebri (avec autopsie) 1, Dyspepsie 1, Phlegmon 1, Amenorrhea 1, Ophtalmia 1, Hydrocephalus 1, Amaurosis 1. Nous avons éliminé 49 cas dans lesquels Cullen et Home n'ont pas posé de diagnostic. Il n'est pas possible, d'après les symptômes énumérés par Cullen et Home, de savoir quel diagnostic ils auraient posé.

Les termes médicaux ci-dessus sont compréhensibles pour nous sauf celui de Synochus. De quoi s'agissait-il ? Voici ce que dit Littré (Dictionnaire de Médecine, $17^{\mathrm{e}}$ éd. 1893): "Synoque [synocha, de $\sigma v^{\prime} \sigma \chi \sigma \varsigma$, continu, de $\sigma v ́ v$, avec, et $\varepsilon \chi \varepsilon v$, tenir; all. synochisches Fieber, angl. synocha, synochus, it. sinoco, esp. sinoco; fièvre continente]. D'une manière générale, toute fièvre qui dure un certain temps, sans intermission et même sans rémission bien marquée... La fièvre in- 
flammatoire des auteurs modernes est le synochus imputris de Galien, qui appelait synochus la maladie nommée depuis fièvre putride, fièvre adynamique.» On trouve en effet dans Galien (Euvres anatomiques, physiologiques et médicales de Galien, traduites par le $\mathrm{D}^{\mathrm{r}}$ Ch. Daremberg, tome 2, 1856) un certain nombre de termes repris par Cullen et par Odier : fièvres éphémères, fièvres intermittentes, péripneumonies, herpès, érysipèle, anthrax, squirre, affections rhumatismales ou. flexionnaires, cataplasmes de farine d'orge avec du vinaigre, emplâtres au cuivre pyriteux, etc.

Enfin il nous faut faire la statistique des cas guéris (cured), soulagés (relieved), améliorés (remitted), renvoyés, congédiés (dismissed), décédés (dead) : Cured 67, remitted 51 , dismissed 26 , dead 10 . Il faut ajouter à ce total 26 cas dans lesquels aucun diagnostic n'a été posé.

On peut s'étonner du grand nombre de patients qui ont été considérés comme étant guéris par Cullen et ses élèves. L'explication en est simple. Dans tous les cas la catamnèse n'est que de quelques jours, parfois d'une ou deux semaines. Dans aucun cas les médecins n'ont eu la curiosité de revoir leurs patients après quelques semaines, mois ou années. Il est donc très probable que dans plusieurs cas la «guérison» n'a été que de courte durée et qu'un grand nombre de patients ont eu des rechutes plus ou moins graves, pouvant même entraîner la mort.

Quant à la thérapeutique, on aura remarqué qu'elle a consisté surtout en saignées, purgations, diète et vomitifs, qui ne pouvaient qu'affaiblir les patients, quelle que soit la maladie diagnostiquée.

\section{Summary}

The History of Science Museum of Geneva owns a very important unpublished manuscript: consultations given at Edinburgh in 1770 by Doctors William Cullen, Louis Odier and Home. 164 "clinical cases" with prescribed treatments fill 10 volumes. In this paper the authors publish 9 cases, 6 of Odier, 2 of Cullen, and one of Home. A statistical table of 164 cases follows, based on the given diagnoses of 164 cases and the results obtained: cure, improvement, or death.

Dr. Marc Cramer

Musée d'Histoire des Sciences

rue Lausanne 128

1202 Genève

Prof. Dr. Georges de Morsier

1, promenade du Pin

1204 Genève 